\title{
Clinical Outcomes of Apnea in Term Newborns
}

\author{
Term Yenidoğan Apnesinin Klinik İlem Sonuçları
}

\author{
Pınar Arıcan $\odot$, Pınar Gençpınar $\odot$, Elif Yiğit $\odot$, Mehmet Yekta Oncel $\odot$, Melek Akar $\odot$, \\ Nihal Olgaç Dündar $\odot$
}

\section{Özgün Araştrrma} Research Article
Alındığı tarih: 04.07.2019

Kabul tarihi: 04.10.2019

Online Yayın tarihi: 28.03.2020

Pınar Gençpınar Department of Pediatric Neurology Izmir Katip Celebi University, Izmir, Turkey

pinargencpinar@gmail.com ORCID: 0000-0002-3223-5408

P. Arıcan 0000-0003-3990-7489 E. Yiğit 0000-0003-1326-9802 Department of Pediatric Neurology, Izmir Tepecik Education and Research Hospital, Izmir, Turkey

N. Olgaç Dündar 0000-0002-5902-3501 Department of Pediatric Neurology, Izmir Katip Celebi University, Izmir, Turkey

M.Y. Oncel 0000-0003-0760-0773 Department of Neonatology, Izmir Katip Celebi University, Izmir, Turkey

M. Akar 0000-0002-0178-2011 Department of Neonatology, Izmir Tepecik Education and Research Hospital, Izmir, Turkey

Cite as: Arıcan P, Gençpınar P, Yiğit E, Oncel MY, Akar M, Olgaç Dündar N. Clinical outcomes of apnea in term newborns. Tepecik Eğit. ve Araşt. Hast. Dergisi. 2020;30(1):1-4.

\section{ABSTRACT}

Objective: Apnea is a common problem in newborns however its clinical outcome is not known well in otherwise healthy newborns. This study is aimed to evaluate the long-term neurodevelopmental outcome of otherwise healthy newborns presenting with apnea.

Method: This study was conducted on 59 children who were hospitalized in neonatal period and consulted with a pediatric neurologist because of apnea

Results: Complete blood counts, C-reactive protein, serum electrolyte and blood glucose levels were within normal levels. Only in one patient, cranial magnetic resonance imaging revealed bleeding in the right temporal lobe. Antiepileptic drug was initiated in $3(5 \%)$ patients with abnormal electroencephalography findings. After discharge from hospital, no patient had recurrent episodes of apnea. Their median follow-up time was 34 months (IQR: 24-41). All patients showed normal psychomotor development. In our study the most common presentation of apnea was a brief resolved unexplained event (BRUE).

Conclusion: Our study has shown that the vast majority of apneic events are self-limiting and require no intervention in otherwise healthy term newborns.

Keywords: Brief resolved unexplained events, epilepsy, apnea

öz

Amaç: Apne, yenidoğanlarda sık görülen bir sorundur ancak sağlıklı yenidoğanlarda nörogelişsimsel sonuçları iyi bilinmemektedir. Bu çalıșmada, apne bașvuran diğer yönlerden sağlıklı yenidoğanların uzun dönem nörogelişimsel sonuçlarını değerlendirmeyi amaçladık.

Yöntem: Bu çalışmaya, yenidoğan döneminde hastaneye yatırılan ve apne nedeni ile pediatrik nöroloğa danışılan 59 çocuk dahil edildi.

Bulgular: Tüm hastaların, tam kan sayımı, C-reaktif protein, serum elektrolitleri ve kan glukozu normaldi. Sadece bir hastada kraniyal manyetik rezonans görüntülemede sağ temporal lobda kanama görüldü. Anormal EEG bulguIarı olan 3 (\%5) hastada antiepileptik ilaç başlanmıştı. Taburculuk sonrası hiçbir hastada tekrarlayan apne atağı görülmedi. Klinik izlem medyan süresi 34 ay (IQR: 24-41) idi. Tüm hastalarda normal nöromotor gelișim gözlendi. Çalışmamızda, en sık görülen apne prezentasyonu kısa çözümlenmiş açıklanamayan olay (BRUE) idi.

Sonuç: Çalışmamız, diğer yönlerden sağlıkı term yenidoğan bebeklerde apneik olayların büyük çoğunluğunun kendi kendini sınırlandırdığını ve müdahale gerektirmediğini gösterdi.

Anahtar kelimeler: Kısa çözümlenmiş açıklanamayan olay, epilepsi, apne

(c) Telif hakkı T.C. Sağlık Bakanlığı İzmir Tepecik Eğit. ve Araşt. Hastanesi. Logos Tıp Yayıncılık tarafindan yayınlanmaktadır. Bu dergide yayınlanan bütün makaleler Creative Commons Atff-GayriTicari 4.0 Uluslararası Lisansı ile lisanslanmıştr.

(c) Copyright Association of Publication of the T.C. Ministry of Health İzmir Tepecik Education and Research Hospital.

This journal published by Logos Medical Publishing.

Licenced by Creative Commons Attribution-NonCommercial 4.0 International (CC BY-NC 4.0) 


\section{INTRODUCTION}

Neonatal apnea is usually defined as a cessation of respiratory flow for 20 seconds or longer, or a shorter respiratory pause associated with bradycardia, cyanosis, pallor, and/or marked hypotonia ${ }^{(1)}$. Apnea in the full-term infant, which occurs at a rate of one per 1000 newborns is not easily understood ${ }^{(2)}$.

Numerous conditions in the newborn may have apnea as a presenting sign. Neonatal apnea could result from sepsis, meningitis, seizure, intracranial hemorrhage or hypoxic ischemic encephalopathy (3,4). The clinical significance and long-term consequences of apneic episodes remain controversial $(5,6)$. Most reports on apnea have been concerned establishing causal relationships with severe co-existing medical problems in affected patients ${ }^{(7,8)}$. In this study, we aimed to evaluate the long-term neurodevelopmental outcome of otherwise healthy newborns presenting with apnea.

\section{MATERIAL and METHODS}

A retrospective study was conducted on children who were hospitalized in neonatal period from January 2014 to February 2018, and consulted with a pediatric neurologist after a solely apneic event. The demographic data, clinical presentation, laboratory tests (complete blood count, C-reactive protein, serum electrolytes, blood glucose, tandem mass spectrometry), neuroimaging, electroencephalography (EEG), echocardiography (Echo) and electrocardiography (ECG) results of patients and clinical follow-up data were collected from the medical records and reviewed. Written informed consents were received from all guardians of the patients.

Patients who were presented with an apneic event in neonatal period and followed clinically for at least 1 year were included in our study. Patients with a history of prematurity, as well as term infants with hypoxic-ischemic encephalopathy or other perinatal complications, newborns with a maternal history of intrauterine infection were not included in the study.

Statistical analysis was performed using Statistical Package for the Social Sciences software program version 21.0 (SPSS Inc., Chicago, IL, USA). Frequencies and percentages were calculated. Patients' age and follow-up times were also expressed using medians and interquartile ranges (IQRs).

\section{RESULTS}

\section{General characteristics of patients (Table)}

Of the 59 patients, 26 (44\%) were girls and 33 (56\%) were boys. Their median age at the onset of apnea was 8 days (IQR: $3-16)$. Twenty-seven (46\%) patients had one, while 32 (54\%) patients had two or more apneic events before attending the hospital. Family history of epilepsy was present in one patient.

\section{Laboratory and radiological findings (Table)}

Complete blood counts, and C-reactive protein, serum electrolytes and blood glucose levels were not remarkable. Tandem mass spectrometry was

Table 1. Demographic characteristics and clinical features of patients.

\begin{tabular}{lc}
\hline Gender, $n$ (\%) & \\
Female & $26(44 \%)$ \\
Male & $33(56 \%)$ \\
Age at the onset of apnea & \\
(median) (IQR) & days (IQR:3-16) \\
Number of apneic events & $27(46 \%)$ \\
1 & $32(54 \%)$ \\
$\geq 2$ & \\
Neuroimaging, $n(\%)$ & $58(98 \%)$ \\
Normal & $1(2 \%)$ \\
Abnormal & \\
EEG, $n$ (\%) & $54(95 \%)$ \\
Normal & $3(5 \%)$ \\
Abnormal & \\
Echo, $n$ (\%) & $30(77 \%)$ \\
Normal & $19(23 \%)$ \\
Abnormal & \\
Antiepileptic Treatment, $n(\%)$ & $3(5 \%)$ \\
Yes & $56(95 \%)$ \\
No & 34 months (IQR:24-41) \\
Follow-up duration (median) & \\
\end{tabular}

EEG: electroencephalography, Echo: echocardiography, IQR: interquartile range. 
performed on 9 patients and examination results were within normal limits in all of them. Cranial ultrasound and/or magnetic resonance imaging (MRI) were performed in all patients. Neuroimaging findings were normal in 58 (98\%) patients. Only in one patient, cranial MRI revealed bleeding from the right temporal lobe.

Electroencephalography was obtained in 57 patients and was normal in 54 (95\%) patients. Antiepileptic drug was initiated in $3(5 \%)$ patients with abnormal EEG findings. Interictal right temporal sharp waves were recorded in two patients and central sharp waves in one patient. Two of 3 patients received levetiracetam and one patient phenobarbital. Cardiologic evaluations were performed in 49 patients. ECG abnormalities were not found in any patient. Abnormal Echo findings were found in 19 (23\%) patients. Thirteen patients had patent foramen ovale, 4 patients had atrial septal defect and 2 patients had ventricular septal defect.

\section{Clinical outcomes}

After discharge from the hospital, none of the patients had recurrent episodes of apnea. Their median of follow-up time was 34 months (IQR: 24-41). All patients showed normal psychomotor development. Three patients under antiepileptic treatment had not any other types of seizures and further apneic attacks Control EEG in all 3 patients did not show any epileptiform activity. Anti-epileptic therapy was discontinued four to six months later.

The patient who had a hemorrhagic area in the right temporal lobe did not receive any antiepileptic drugs and he had not suffered from any other types of seizures and further apneic attacks. Three patients who had normal EEG and neuroimaging findings had experienced single seizures during follow-up. One of 3 patients, had afebrile seizure at 3 months of age and two patients had febrile seizures at 10 and 14 months of age, respectively.

\section{DISCUSSION}

The most common presentation of apnea was a brief resolved unexplained event (BRUE) in our study. BRUE has been described by The American Academy of Pediatrics in 2016. A BRUE is defined as an event occurring in an infant younger than 1 year and characterized by cyanosis or pallor; absent, decreased, or irregular breathing; marked change in tone; or altered responsiveness. Moreover, diagnosis of BRUE can be made only when there is no explanation for an apneic event after conducting an appropriate anamnesis and physical examination. Pathophysiology of these events is still unknown. Abnormalities in the swallowing mechanisms, laryngospasm, gastroesophageal reflux or autonomic function may play a role in pathophysiology (9). Fifty-five (93\%) patients had BRUE as a presenting sign of an apneic event. The patients with BRUE without an apparent etiology were identified and these patients had no longer experienced a BRUE after neonatal period.

Rarely, apnea occurs as an isolated seizure phenomenon unaccompanied by other clinical epileptic features ${ }^{(10)}$. Apneic seizures are thought to originate from the temporal lobe ${ }^{(11)}$. Ramelli et al. ${ }^{(12)}$ reported four infants with epileptic apneic attacks. Although the authors concluded that epileptic apnea could be associated with a poor outcome, their patients' psychomotor development was mildly retarded before apneic events and they had also other types of seizures. In our study, MRI demonstrated intraparenchymal hemorrhage in the right temporal in one patient $(2 \%)$. Three patients $(5 \% ; 3 / 59)$ had recurrent epileptic apnea and received antiepileptic treatment. The patient who had right temporal hemorrhage, experienced only one apneic event and EEG was normal, and he did not receive any antiepileptic drugs. Our patients who were otherwise healthy and had no other types of seizures showed normal psychomotor development. 
While the literature on the cause of apnea in term infants and the yield of the diagnostic workup is extensive, there is little knowledge about its longterm outcome ${ }^{(3,13)}$. The study of Levin et al. (2) demonstrated that apnea is associated with higher length of stay and cost in the newborn hospitalization, with variation in hospital practice. Pillekamp et al. ${ }^{(5)}$ concluded more severe courses than expected for postmenstrual age or the resolution at a later postmenstrual age indicated an increased risk of neurodevelopmental disturbances. These conditions by themselves contribute to poor neurodevelopmental outcome.

In our study, the median follow-up period was 34 months and the patients showed normal psychomotor development. We did not detect any further apneic attacks and epileptic seizures in infancy which may be related to maturation of the center of temperature control and feeding pattern. Apneic events resolved by the time the patients were ready for hospital discharge as determined by maturation of center of temperature control and feeding pattern.

The limitations of this study are its retrospective design and small sample size. Further multicenter prospective studies are required to determine the outcomes of apnea in term newborns.

In conclusion, obtaining a thorough history and performing a detailed physical examination is important for the evaluation of a term newborns presenting with apnea. Our study showed that the vast majority of apneic events are self-limiting and require no intervention in otherwise healthy term newborns.
Ethics Committee Approval: T. C. Izmir Katip Çelebi University Rectorate Non-Interventional Clinical Research Ethics Committee approval was received (25.04.2018/177).

Conflict of Interest: The authors declare that they have no conflict of interest.

Funding: The authors received no financial support for the research, authorship, and or publication of this article.

Informed Consent: Informed consent was obtained.

\section{REFERENCES}

1. American Academy of Pediatrics. Apnea, sudden infant death syndrome, and home monitoring. Pediatrics. 2003;111:914-7. [CrossRef]

2. Levin JC, Jang J, Rhein LM. Apnea in the otherwise healthy, term newborn: national prevalence and utilization during the birth hospitalization. J Pediatr. 2016;181:67-73. [CrossRef]

3. Sale SM. Neonatal apnoea. Best Practice \& Research Clinical Anaesthesiology. 2010;24(3):323-36. [CrossRef]

4. Hoogstraate SR, Lequin MH, Huysman MA, Ahmed S, Govaert PP. Apnoea in relation to neonatal temporal lobe haemorrhage. Eur J Paediatr Neurol. 2009;13:356-61. [CrossRef]

5. Pillekamp F, Hermann C, Keller T, Von Gontard A, Kribs A, Roth B. Factors influencing apnea and bradycardia of prematurity-implications for neurodevelopment. Neonatology. 2007;91:155-61. [CrossRef]

6. Martin RJ, Fanaroff AA. Neonatal apnea, bradycardia, or desaturation: Does it matter? J Pediatr. 1998;132:758-9. [CrossRef]

7. Chirico G, Beccagutti F. Nasal obstruction in neonates and infants. Minerva Pediatr. 2010:62(5);499-505.

8. Koons AH, Mojica N, Jadeja N, Ostfeld B, Hiatt M, Hegyi T. Neurodevelopmental outcome of infants with apnea of infancy. Am J Perinatol. 10:208-11. [CrossRef]

9. Tieder JS, Bonkowsky JL, Etzel RA, Franklin WH, Gremse DA, Herman B, et al. Brief resolved unexplained events (formerly apparent life-threatening events) and evaluation of lowerrisk infants. Pediatrics. 2016;137:e20160590. [CrossRef]

10. Tramonte JJ, Goodkin HP. Temporal lobe hemorrhage in the full-term neonate presenting as apneic seizures. J Perinatol. 2004;24:726-9. [CrossRef]

11. Sirsi D, Nadiminti L, Packard MA, Engel M, Solomon GE. Apneic seizures: a sign of temporal lobe hemorrhage in fullterm neonates. Pediatr Neurol. 2007;37:366-70. [CrossRef]

12. Ramelli GP, Donati F, Bianchetti M, Vassella F. Apnoeic attacks as an isolated manifestation of epileptic seizures in infants. Eur J Paediatr Neurol. 1998;2:187-91. [CrossRef]

13. Veit L, Amberson M, Freiberger C, Montenegro B, Mukhopadhyay S, Rhein LM. Diagnostic evaluation and home monitor use in late preterm to term infants with apnea, bradycardia, and desaturations. Clin Pediatr. 2016;55:1210-218. [CrossRef] 